\title{
The Swedish Gamble and the Battle to Combat the COVID-19 Pandemic: Evidence from the Field
}

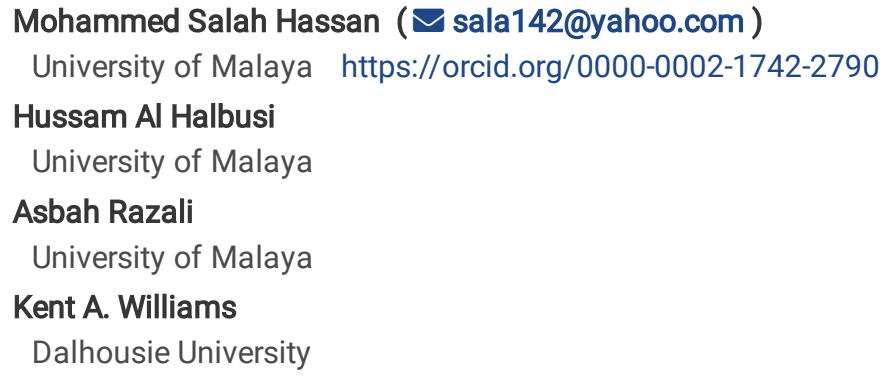

\section{Research Article}

Keywords: Risk Perception, Trust in Government, Satisfaction with Government Measures, Self-Efficacy, COVID-19

Posted Date: September 18th, 2020

DOI: https://doi.org/10.21203/rs.3.rs-78258/v1

License: 두 (i) This work is licensed under a Creative Commons Attribution 4.0 International License. Read Full License

Version of Record: A version of this preprint was published at Current Psychology on September 18th, 2020. See the published version at https://doi.org/10.1007/s12144-022-02947-w. 


\section{Abstract}

Governments around the world have issued movement restrictions and quarantine to combat the SARS-CoV-2 (COVID-19) pandemic. However, the Swedish government has not implemented such measures but rather depended on individual responsibility. An important question regarding the extent to which individuals have been encouraged to trust in and be satisfied with government strategies and adopt personal health measures, such as social isolation, remains unanswered. This study aims to examine the direct effects of trust in the government and risk perception on self-efficacy. Most importantly, this study intends to explore whether satisfaction with government measures augments the relationships between trust in the government and self-efficacy and between risk perception and self-efficacy. Thus, we test our suggested hypotheses using survey data obtained from 403 Swedish citizens living in Sweden, and as predicted, the findings indicate that trust in the government and risk perception positively impact individual self-efficacy. Additionally, the findings reveal that satisfaction with government measures strengthens this relationship; more precisely, the impact of trust in the government and risk perception under a high level of individual satisfaction with government measures is much more positive than that under a low level of satisfaction. In practice, a focus on implementing successful policies or strategies and excellent individual self-efficacy are required to halt the pandemic, and the findings indicate that combining strictly attentive and adaptive individual strategies with government strategies can minimize the spread of infection.

\section{Introduction}

Governments and health care systems around the world are facing the greatest public challenge since World War II due to the COVID-19. As SARS-CoV-2 has spread to every continent, resulting in billions of people going into quarantine and stay at home orders as health services fight to cope (Wltz 2020; WHO 2020).

According to the World Health Organization (2020), on June 9, 2020, Sweden had 4,694 deaths and 45,133 confirmed cases; worldwide, there were more than 7 million infections (WHO 2020). Sweden's first case of COVID-19 was confirmed on February 3, 2020 (WItz 2020).

Subsequently, the Swedish government has not undertaken any major strategies to combat the COVID-19 outbreak in the country and instead employed a less restrictive policy than its neighbors and other countries worldwide; schools, restaurants, and shopping centers all remain open even though the World Health Organization has highlighted social distancing strategies as the main method for reducing the spread of the virus. Nevertheless, Sweden has not implemented any lockdowns and mostly relies on cautioning citizens and recommending protective measures, thus relying on Swedish citizens' sense of social responsibility (Prime Minister's Office 2020). Thus, the Swedish government's approach to addressing the outbreak has been very controversial, and some scientists argue that Sweden is adopting a policy similar to a herd immunity policy. While Swedish officials have denied that they are pursuing such a policy, the Swedish ambassador to the United States has said that "about 30 percent of people in Stockholm have reached a level of immunity" (Mai 2020).

In addition, an appeal signed by Carl-Henrik Heldin, Chairman of the Nobel Foundation, and 2,000 Swedish scholars on 28 March, urged the government of Sweden to "immediately take steps to comply with the World Health Organization's recommendations". Although the government has denied implementing herd immunity strategies, the petition argues that Sweden's reaction to the COVID-19 outbreak is indeed a herd immunity policy while stating that "Creating herd immunity, in the same way that occurs during an influenza epidemic, has low scientific support". Other scholars have mentioned that "these measures must be in place as soon as possible, as is currently the case in our European neighboring countries" and "our country should not be an exception in the work to curb the pandemic" (Reynolds 2020). Therefore, regardless of whether Sweden's government is attempting to implement a herd immunity strategy, the adopted approach is very controversial as Sweden is among the few countries that have not implemented any major lockdown in contrast to most other countries worldwide (Meunier 2020).

In conclusion, the COVID-19 pandemic is profoundly dependent on how the public reacts to such an outbreak and how the government responds to limit the hazard. Hence, empirical evidence from the field regarding how satisfied Swedish people are with the actions executed by the government and how such satisfaction shapes their risk perception and self-efficacy, which is important for understanding how the strategies used shape citizens' behavior, is lacking (Feldman 2020). Therefore, this study aims to explore the Swedish people's level of satisfaction with the policy measures implemented in Sweden, the effect of such satisfaction on their risk perception and self-efficacy, and how Sweden's strategies shaped individual behavior during the pandemic. More precisely, this study observes the direct effect of trust in the government and risk perception on self-efficacy and explores whether satisfaction with government measures augments the positive effect of trust in the government and risk perception on self-efficacy. Figure 1 shows the proposed research model.

\section{Theoretical Background}

\section{Risk Perception and Self-Efficacy}


Risk perception refers to a person's perception toward a health incident (e.g., diseases) to occur (Slovic 2000; El-Toukhy 2015). Risk perception depends on the following two factors: the first factor is severity, which refers to the person's perception of the ferocity of a certain disease (Rimal and Real, 2003), and the second factor is susceptibility, which reflects a person's perception of the possibility of being infected with a disease (El-Toukhy 2015; Choi, Yoo, Noh, and Park, 2017).

People tend to perceive risk particularly strongly when a public health hazard occurs (Pask and Rawlins, 2016), such as during the H1N1 flu and MERS outbreaks, as the emergence of an infectious virus leads the public to immediately assess the disease risks (Oh, Eom, and Rao 2015; B. Reynolds and Seeger, 2005). Thus, examining how the community perceives risk related to a public health hazard can help in the management of public behavior to avoid more infections and promote preventive measures. It is vital to examine how risk perception is affecting the formation of self-efficacy beliefs throughout a public emergency (Choi et al. 2017). Therefore, the combination of the extended parallel process model and the protection motivation theory assist in the conceptualization of risk perception in this study, hence, risk perception is explained in relation to perceived severity and susceptibility, which together constitute peoples' risk perception. Additionally, some theories suggest that risk perception is the primary reason driving people to adopt preventive measures and promote protective behaviors (self-efficacy) during a health crisis (Rogers 1983; Witte 1992); hence, the conceptualization of risk perception must consider the importance of self-efficacy as a high level of perceived risk is necessary for the adoption of recommended health behaviors (self-efficacy). People's risk perception is a key element motivating their self-efficacy to change their health behavior (Rimal and Real, 2003).

Furthermore, self-efficacy is a person's belief in their capability to manage difficulties during a public health crisis (Bandura 1997). Selfefficacy plays a vital role in encouraging individuals' motivation to manage personal difficulty during a crisis (Bandura, 1990). A prominent definition of this construct by Bandura 1990 (p. 28) describes perceived self-efficacy as "the capacity to exercise self-influence by personal challenge through goal setting and evaluative reaction to one's performances". Furthermore, as per the social cognitive theory (Bandura 1997), self-efficacy is considered as a form of "personal control" over one's behavior, resulting in a change in health behavior during a health crisis. The social cognitive theory further argues that the adaptation of health behavior and avoidance of impairing behaviors during a public health crisis is difficult as most individuals find it difficult to change their behavior; however, this difficulty depends on the effect of individuals' perceived risk of a hazard. Therefore, risk perception shapes peoples' beliefs regarding their cognitive ability to adapt to or refrain from certain behaviors during a crisis (Bandura and Watts, 1996; Slovic 2000). Risk perception and self-efficacy play a critical role during a public health hazard as they promote the adaptation of health behaviors among the public and help maintain such a change during a crisis (Bandura and Watts, 1996). Risk perception shapes personal self-efficacy; however, risk perception differs in its effect on how people feel and act. Regarding behavior, self-efficacy can enhance individuals' eagerness to act like those with high self-efficacy are likely to achieve better during a challenging task because they establish higher goals and are committed toward achieving such goals (Locke and Latham, 1990). Hence, self-efficacy behaviors during a public health crisis lead to enhanced personal motivation, which could lead to changes in behavior and perception (Dorsey, Miller, and Scherer, 1999).

Regarding feelings, individuals with low self-efficacy experience helplessness during a crisis depending on how they perceive the risk of a crisis and their ability to control their behavior (Schwarzer and Fuchs 1996). This phenomenon has been examined by scholars who have highlighted the relationship between risk perception and self-efficiency, demonstrating that public risk perception shapes their self-efficacy throughout public health emergencies (Coleman and Iso-Ahola 1993; Han, Zhang, Chu, and Shen, 2014). Studies also highlight that people's self-efficacy beliefs promote confidence in their ability to control their behavior during a crisis; hence, risk perception shapes these beliefs and is a major predictor of self-efficacy (Han et al. 2014). However, the relationship between risk perception and self-efficacy highly depends on various factors. This study proposes that this relationship is affected by people's trust in the government and satisfaction with its measures during a pandemic. Hence, the model proposed in this study further examines the factors shaping people's risk perception and self-efficiency during the COVID-19 pandemic.

\section{Trust in the Government and Self-Efficacy}

Different countries have reacted in different ways to the epidemic. This study aims to investigate the social and psychological factors that will shape the current pandemic. A social sciences standpoint will aid the understanding of the mortality during the COVID-19 pandemic. However, social aspects, which should always be examined in their ecological setting, are imperative in epidemics (Morse 1996). For instance, the spread of a virus is impacted by public social activity. European nations significantly diverge in their population density, and variances also occur in the social interaction individuals have on a day-to-day basis (Sorokowska et al. 2017). Hence, this will result in a key cultural variance in the physical distance persons keep while interacting with other individuals (Latané, Liu, Nowak, Bonevento, and Zheng 1995). For example, countries located in southern Europe traditionally been considered to be a contact culture, while cultures in northern Europe and Asia are highlighted as a noncontact. During a pandemic, the spread of diseases is deeply dependent on the physical and social closeness of people (Remland, Jones, and Brinkman 1995; Sorokowska et al. 2017). 
Another central social aspect is trust in government. As it a vital factor for the safety of societies and the overall functioning of a country (Newton 2001; Uslaner 2002). In particular, trust in government institutions is a central part of management and prevention during a public health crisis since trust in public organizations, such as health care systems, shapes the public interaction with public institution and following preventive measures (Rowe and Calnan 2006). Thus, trust in government plays a critical role during a public emergency (Dinesen and Jæger 2013; Norris, Stevens, Pfefferbaum, Wyche, and Pfefferbaum 2008). Investigation in previous epidemics has highlighted that individuals who demonstrate a low level of trust in the government were less likely to adopt preventive measures during the Ebola virus outbreak in 2014 (Blair, Morse, and Tsai 2017; Vinck, Pham, Bindu, Bedford, and Nilles 2019). This phenomenon was also noted in Hong Kong during the SARS outbreak (Tang and Wong 2005). Similarly, during the H1N1 virus epidemic in the United Kingdom, greater trust in authorities was associated with engaging in preventive behaviors (James Rubin, Amlôt, Page, and Wessely 2009).

Several previous studies have substantiated the difference in trust in government around the world, rendering consideration of the societal element of trust essential (Marien and Werner 2019; Sønderskov and Dinesen 2016). Compared to other countries, Nordic countries (e.g., Finland, Denmark, Iceland, Norway, and Sweden) trust in public organizations is characteristically higher according to different international welfare statistics (Marozzi 2015). On the other hand, in Italy and other southern European countries, trust in government institutions is low (Hudson 2006; OECD 2020). The determinants of trust in government differ across Europe. In East-Central Europe, senior citizens have been found to demonstrate high level of trust, while trust in government establishments is lower among educated individuals (Boda and MedveBalint 2014). In southern European countries, such as Spain and Italy, people's attitudes toward government and trust in these public institutions are extremely entrenched in "cultural legacy" (Cole and Cohn, 2016). The combination of lack of trust in government and physicalsocial closeness might become fatal in Europe. Therefore, based on the aforementioned arguments, trust in authority is important. The Swedish government has implemented measures that differ from those implemented in other countries during the current pandemic, and the success of these measures is associated to the degree of trust between the public and authorities, which is likely to helps build individual confidence and self-efficacy among individuals to avoid risk during the pandemic (Ter Huurne and Gutteling 2009; Thaker, Howe, Leiserowitz, and Maibach 2019).

\section{Contingent Role of Satisfaction with Swedish Government Measures}

During the COVID-19 outbreak, common strategies adopted by most affected countries included lockdowns and stay-at-home orders as measures to keep citizens separated and break the chain of transmission. However, Sweden adopted a very different method to combat the COVID-19 outbreak, and primary schools, restaurants, bars, gyms, and public parks have remained open. However, companies are encouraged to allow their employees to work from home at their discretion.

Anders Tegnell, a top chief epidemiologist, advocated for such strategies and refused to implement WHO guidelines regarding lockdowns and quarantines. Deputy prime minister Isabella Lövin defended this strategy and noted that Sweden considers the COVID-19 pandemic a "marathon, and not a sprint" and that citizens in countries that implement strict measures eventually do not obey these measures (Anderson 2020). Thus, Sweden's measures addressing COVID-19 are based on the critical element of citizen responsibility, while the government highlights the necessary actions, such as social distancing with elderly individuals, and provides full autonomy to its citizens (Rolander 2020). In particular, the Swedish prime minister recently said that "our government agencies and our health care system are doing everything they can. However, every person in Sweden needs to take individual responsibility. If everyone takes responsibility, we can keep the spread of the virus in check. Follow the authorities' advice: if you have even the slightest symptoms, do not go to work and refrain from meeting other people" (Prime Minister's Office 2020).

However, based on the number of deaths and infections linked to COVID-19, Sweden has high infection and death rates, especially in senior homes. The Swedish health care system has not been burdened with a large number of hospitalized patients as Sweden has a large ICU capacity (Anderson 2020). In addition, the success or failure of Sweden's response to the COVID-19 outbreak will be unclear for many months, but the main determinant of the success of such a policy could be whether Sweden can achieve natural herd immunity, however, the success of any policy in Sweden is fundamentally dependent on the public satisfaction with unique measures employed by the government.

\section{What is Natural Herd Immunity}

COVID-19 is triggered by a new zoonotic coronavirus that emerged in China in 2019 (Zhu et al. 2020). Meanwhile, the COVID-19 pandemic has affected more than 202 countries worldwide and resulted in more than 3 million infections. SARS-CoV-2 is extremely infectious and can be spread via droplets. Different nations have pursued diverse strategies to combat the spread of infections, and the most popular policy used is social distancing; however, Sweden, have implemented different policies, the results of these measures will likely promote reaching herd immunity (Reynolds 2020). 
Herd immunity is a well-known concept in the field of epidemiology and has previously been a successful strategy. Before the development of vaccines, herd immunity was the only line of defense against infections. Nevertheless, there are numerous definitions of this concept. Based on the literature, natural herd immunity is understood as immunity that naturally occurs when people become immune to disease after being infected. The natural immune system response is triggered when the human body starts to produce antibodies against the virus that cause the infection. The antibodies act as a safeguard against any future infection from specific diseases, and if a person who develops these antibodies after the infection encounters the same virus, the antibody will protect that person from reinfection (Anderson and May 1985; Fine 1993).

The most recognized descriptions of herd immunity was provided by Fox (1983 p. 463), who defines this concept as "the resistance of a group to attack by a disease to which a large proportion of the members are immune, thus lessening the likelihood of a patient with a disease coming into contact with a susceptible individual"; Fox further added that the theory of herd immunity holds that the individual transmission chain of infectious diseases is likely to break when most of the population is immune, and thus, the higher the number of people immune to the disease, the lower the number of people who become infected. Additionally, Metcalf, Ferrari, Graham, and Grenfell (2015 p. 753) highlighted herd immunity as a "population-scale immunity," indicating that for herd immunity to be effective, approximately $70 \%$ of the population must have immunity through either vaccination or naturally acquired immunity(d'souza and dowdy 2020). Herd immunity is successful when immune people break the chain of infection by being unable to transmit the disease as this likely slows or stops the spread of the virus. As there is no vaccine available for COVID 19, this study focuses on naturally acquired immunity, which is called natural herd immunity. In contrast, vaccine immunity occurs when most of the population has gained immunity through the use of a vaccine for a certain disease as in the case of smallpox. Through the use of vaccines (John and Samuel 2000), many people developed immunity against the virus, and as of 1980 (Fenner, Henderson, Arita, Jezek, and Ladnyi 1988), smallpox was declared eradicated. Herd immunity has the ability if achieved, to the elimination of specific diseases (Williams 2006).

The SARS-CoV-2 virus is similar to other coronaviruses, specifically in terms of their genetic code, and researchers argue that individuals who become infected with the virus can develop immunity for months and possibly years (d'souza and dowdy 2020). While the Swedish government has declared that its approach to combating COVID-19 is not a herd immunity approach, most news outlets and researchers claim that Sweden's approach is similar to the natural herd immunity strategy. Swedish government representatives have noted that even though Sweden is not adopting an explicit herd immunity strategy, the principle of the herd immunity approach is "in there in the mix" (Brueck 2020). Thus, according to a recent study, for the "herd immunity" approach to be successful in Sweden, $70.9 \%$ of the population must be immune to the virus (Kwok, Lai, Wei, Wong, and Tang 2020).

On April 24, twenty-two Swedish doctors and researchers criticized the government's strategy and argued that the approach is doomed to fail and must be changed immediately; they highlighted the need for social distancing measures to be strictly enforced by the government (Nikel 2020; Nyheter 2020). Hence, in this study, we examine how satisfied Swedish people are with the current measures implemented by the government and how such satisfaction shapes people's risk perception and self-efficacy throughout the pandemic.

Based on the overall literature, we hypothesize that trust in the government has a positive influence on individual self-efficacy (H1) and that individuals who experience high risk perception this will positively impact their self-efficacy (H2). Importantly, we predict that the positive relationship between trust in the government and individual self-efficacy is strengthened as Swedish citizens display a higher level of satisfaction with the Swedish government's measures (H3a). Similarly, H3b asserts that the positive association between risk perception and individual self-efficacy increases as Swedish citizens show higher levels of satisfaction with the Swedish government's measures as indicated in Figure 1. Therefore, the following hypotheses are suggested in this study:

- Hypothesis 1. Trust in the government is significantly associated with self-efficacy.

- Hypothesis 2. Risk perception is significantly associated with self-efficacy.

- Hypothesis 3a. Satisfaction with government measures moderates the relationship between trust in the government and individual selfefficacy in such a way that the relationship is stronger among individuals who are highly satisfied with government measures than among individuals who are less satisfied with government measures.

- Hypothesis $\mathbf{3 b}$. The relationship between risk perception and self-efficacy is moderated by the individual satisfaction with the government measures to combat COVID-19, in such a way that the relationship is stronger among individuals who are highly satisfied with government measures than among individuals who are less satisfied with government measures.

\section{Method And Materials}

Having an accurate and sufficient sample size is very important (Ryan 2020). Therefore, in the current study, G-Power 3.1 was employed to determine the appropriate sample size (Faul, Erdfelder, Lang, and Buchner 2007). Relying on the criteria proposed by Cohen (1992), the 
preferable power is greater than 0.80 , such as 0.90 or 0.95 , with a mediating effect size of 0.15 . However, according to the abovementioned criteria, the minimum sample size required to examine the proposed research model with three predictors is 108 cases. Thus, we gathered our data from 403 Swedish citizens currently living in Stockholm and Småland in Sweden. The survey was carefully designed in a Google Form and began with a cover letter that was sent to 500 individuals.

Of 500 questionnaires, only 403 responses were returned, yielding a response rate of $80 \%$. We collected information regarding the participants' location, age, gender, and education. Regarding location, $47.4 \%$ of the participants were from Småland, and $52.6 \%$ of the participants were from Stockholm. Regarding age, $6.0 \%$ of the participants were aged under 25 years, $43.2 \%$ of the participants were aged between 25 and 30 years, $36.2 \%$ of the participants were aged between 31 and $40,10.7 \%$ of the participants were aged between 41 and 50 , and $4.0 \%$ of the participants were aged 51 or above. Regarding gender, $33.5 \%$ of the respondents were male, and $66.5 \%$ of the respondents were female. Regarding the educational level, $1.5 \%$ of the respondents had completed only high school, $50.1 \%$ of the respondents held a bachelor's degree, $33.7 \%$ of the respondents held a master's degree, and $14.6 \%$ of the respondents held a doctorate degree.

\section{Measures}

All measures were obtained from the literature and, thus, were assessed by a 5-point Likert scale. Trust in the government was measured with 3 items obtained from Grimmelikhuijsen (2012). One item was as follows: "During the current pandemic, the government has cared about the well-being of citizens". Eight items were adopted from Rubin et al. (2014) to evaluate risk perception, and one item was as follows: "I have little control over whether I will catch COVID-19 (SARS-CoV-2)". Satisfaction with government measures was measured with 4 items obtained from Willems, Knassmüller, Ebinger, Dinhof, and Schmid (2020). One item was as follows: "How satisfied are you with how you are complying with government measures to cope with the COVID-19 crisis". Five items were adapted from Rimal and Real (2003) to measure self-efficacy. One item was as follows: "I am confident in my ability to protect myself from COVID-19 (SARS-CoV-2)". Finally, age, gender, and education served as control variables to rule out alternative explanations of our findings and reduce errors (Becker, 2005). Age and education were measured with an ordinal scale anchored between 1 (younger, lower education) and 5 (older, higher education). However, gender was dichotomized $(0=$ male, $1=$ female $)$.

\section{Data Analysis and Results}

For several reasons, structural equation modeling (SEM) with partial least squares (PLS) using Smart PLS 3.2.9 software (Henseler, Ringle, and Sarstedt 2015) was performed as a suitable and appropriate option to evaluate the proposed hypotheses. As this efficient, robust statistical method does not require strict assumptions about variables distribution and is suitable for complex causal analysis of both lower order-construct and higher-order constructs (; Henseler, Ringle, and Sinkovics, 2009; Hair, Hult, Ringle, and Sarstedt 2017). In addition, we evaluated the statistical path coefficients by using 5,000 subsample algorithms to produce $n-1$ degrees of freedom bootstrap t-statistics (where $\mathrm{n}$ is the number of subsamples).

\section{Common Method Variance (CMV)}

Because our data were obtained from the same single data source, various actions were implemented to minimize the risk of common method variance (Podsakoff, MacKenzie, Lee, and Podsakoff 2003; MacKenzie and Podsakoff 2012). Firstly, the subjects were provided explanations of each construct and specific instructions on how to fulfill the assessments to prevent ambiguity. Also, the participants were told that their names were confidential and that the research was scientific in nature.

On top of that, alongside these methodological remedies ex-ante, we carried out multiple post-hoc studies to determine the possibility of CMV biasing the results. Since CMV cannot inflate our terms of interaction (MacKenzie and Podsakoff 2012), which is this study's central focus, we decided to check for this problem. First, Harman's (1976) single-factor test approach was used to estimate common method variance (CMV), thus the outcome of this test revealed any concerns; an exploratory factor analysis was employed to whether a single factor might explain much of the covariance among the items in the sample. The test showed five variables greater than 1, which accounted for 68 percent of the overall variance, and only 29 percent of the overall variance was accounted for by the variance in the first factor. Consequently, this check indicates CMV is not a serious concern (Podsakoff et al., 2003). Second, we also carried out a complete collinearity check centered on inflationary variance factors (VIFs) (Kock 2015). Thus, the guidelines defined by Kock and Lynn (2012), were faithfully followed which suggested such a test for both vertical and lateral collinearity assessments. Kock and Lynn (2012) note that pathological collinearity is suggested by a VIF with a higher value than 3.3, indicating that the model could be loaded with CMV. However, as shown in Table 1, this study is considered free of CMV. 


\begin{tabular}{|lllll|}
\hline \multicolumn{4}{|l|}{ Table 1. Full Collinearity Estimate Criteria (Common Method Bias Assessment) } \\
\hline Variable & Risk Perception & Satisfaction with Government Measures & Self-Efficacy & Trust in the Government \\
\hline VIF & 1.308 & 1.151 & 1.267 & 1.137 \\
\hline Note: $\mathrm{VIF}=$ & Variance inflation factor & &
\end{tabular}

\section{Measurement Model Assessment}

According to Hair et al. (2017), before using a structural model, its characteristics (item reliability, internal consistency reliability, convergent validity, and discriminant validity) should be confirmed. Therefore, these features were all checked and described as follows: we began with item reliability. As shown in Table 2, most items were greater than the threshold level of 0.707 (Hair et al. 2017 ; Hair, Risher, Sarstedt, and Ringle 2019). To measure the constructs' internal consistency, we used Cronbach's alpha and composite reliability. Table 2 indicates that both techniques showed satisfactory values ranging from 0.802-0.856 and 0.796-0.893, which were higher than the 0.70 cutoffs (Hair et al. 2017; Hair et al. 2019). Regarding convergent validity, the average variance extracted (AVE) also achieved values ranging from $0.517-0.737$, which exceeded the threshold of 0.5 (Hair et al. 2017; Hair, et al. 2019) (see Table 2). 
Table 2. Measurement Model, Item Loadings, Construct Reliability and Convergent Validity.

\begin{tabular}{|c|c|c|c|c|c|c|}
\hline Constructs & Labeled & Indicator Descriptions & $\begin{array}{l}\text { Loading } \\
(>0.5)\end{array}$ & $\begin{array}{l}\text { CA } \\
(> \\
0.7)\end{array}$ & $\begin{array}{l}\text { CR } \\
(> \\
0.7)\end{array}$ & $\begin{array}{l}\text { AVE } \\
(> \\
0.5)\end{array}$ \\
\hline \multirow[t]{3}{*}{$\begin{array}{l}\text { Trust in the } \\
\text { Government }\end{array}$} & TIG01 & $\begin{array}{l}\text { During the COVID- } 19 \text { pandemic, the government has cared about } \\
\text { the well-being of citizens. }\end{array}$ & 0.869 & 0.820 & 0.893 & 0.737 \\
\hline & TIGO2 & $\begin{array}{l}\text { During the COVID-19 pandemic, the government has kept its } \\
\text { promises. }\end{array}$ & 0.798 & & & \\
\hline & TIGO3 & $\begin{array}{l}\text { During the COVID- } 19 \text { pandemic, the government has carried out } \\
\text { its duties effectively. }\end{array}$ & 0.904 & & & \\
\hline \multirow[t]{8}{*}{ Risk Perception } & RISP1 & $\begin{array}{l}\text { If I don't take any preventive action, then I am likely to catch } \\
\text { COVID-19 (SARS-CoV-2). }\end{array}$ & 0.630 & 0.848 & 0.882 & 0.683 \\
\hline & RISP2 & $\begin{array}{l}\text { I have little control over whether I will catch COVID-19 (SARS- } \\
\text { CoV-2). }\end{array}$ & 0.724 & & & \\
\hline & RISP3 & COVID-19 (SARS-CoV-2) would be a serious illness for me. & 0.665 & & & \\
\hline & RISP4 & $\begin{array}{l}\text { If I catch COVID-19 (SARS-CoV-2), it will have major } \\
\text { consequences on my life. }\end{array}$ & 0.704 & & & \\
\hline & RISP5 & COVID-19 (SARS-CoV-2) would be a mild illness for me. & 0.674 & & & \\
\hline & RISP6 & $\begin{array}{l}\text { If I catch COVID-19 (SARS-CoV-2), it will have a large effect on } \\
\text { me. }\end{array}$ & 0.729 & & & \\
\hline & RISP7 & $\begin{array}{l}\text { If I catch COVID-19 (SARS-CoV-2), it will have serious financial } \\
\text { consequences for me. }\end{array}$ & 0.682 & & & \\
\hline & RISP8 & $\begin{array}{l}\text { If I catch COVID-19 (SARS-CoV-2), it will cause difficulties for } \\
\text { people who are important to me. }\end{array}$ & 0.747 & & & \\
\hline \multirow{4}{*}{$\begin{array}{l}\text { Satisfaction with } \\
\text { Government } \\
\text { Measures }\end{array}$} & SWGM1 & $\begin{array}{l}\text { How satisfied are you with how you are complying with the } \\
\text { government measures to cope with the COVID- } 19 \text { crisis? }\end{array}$ & 0.738 & 0.856 & 0.796 & 0.517 \\
\hline & SWGM2 & $\begin{array}{l}\text { How satisfied are with how the federal government is addressing } \\
\text { the COVID-19 crisis? }\end{array}$ & 0.749 & & & \\
\hline & SWGM3 & $\begin{array}{l}\text { How satisfied are you with how the federal government is } \\
\text { communicating its measures for coping with the COVID-19 } \\
\text { crisis? }\end{array}$ & 0.740 & & & \\
\hline & SWGM4 & $\begin{array}{l}\text { How satisfied are with how the Swedish population overall is } \\
\text { complying with the measures enacted by the government to cope } \\
\text { with the COVID-19 crisis? }\end{array}$ & 0.918 & & & \\
\hline \multirow[t]{5}{*}{ Self-Efficacy } & $\begin{array}{l}\text { Self- } \\
\text { Eff1 }\end{array}$ & $\begin{array}{l}\text { I am confident in my ability to protect myself from COVID-19 } \\
\text { (SARS-CoV-2). }\end{array}$ & 0.878 & 0.802 & 0.866 & 0.573 \\
\hline & $\begin{array}{l}\text { Self- } \\
\text { Eff2 }\end{array}$ & $\begin{array}{l}\text { I am certain that I will take the required actions even if they are } \\
\text { difficult or inconvenient. }\end{array}$ & 0.911 & & & \\
\hline & $\begin{array}{l}\text { Self- } \\
\text { Eff3 }\end{array}$ & I have the willpower to engage in precautionary actions. & 0.789 & & & \\
\hline & $\begin{array}{l}\text { Self- } \\
\text { Eff4 }\end{array}$ & I am confident that I can carry out precautionary actions. & 0.613 & & & \\
\hline & $\begin{array}{l}\text { Self- } \\
\text { Eff5 }\end{array}$ & $\begin{array}{l}\text { I am certain that I can control myself to reduce the chances of } \\
\text { contracting COVID-19 (SARS-CoV-2). }\end{array}$ & 0.518 & & & \\
\hline
\end{tabular}


Additionally, the AVE and heterotrait-monotrait ratio (HTMT) tested for discriminating validity. As seen in Table 3, there is no significant issue of distinguishing validity, since each construct's AVE was larger than that of the variance that each construct shared with the other latent variables (Hair et al. 2017). Also, the HTMT values were below 0.90, which indicates the discriminating validity of a set of variables. Both HTMT values varied substantially from 1, and the confidence intervals of 95 percent (CI) did not include 1 (Henseler et al., 2015 ), indicating the discriminating validity of each set of vertices.

Table 3. Descriptive Statistics, Correlation Matrix, and Discriminant Validity.

\begin{tabular}{|c|c|c|c|c|c|c|c|c|c|}
\hline & Mean & SD & 1 & 2 & 3 & 4 & 5 & 6 & 7 \\
\hline \multirow{2}{*}{$\begin{array}{l}\text { 1. Trust in } \\
\text { the } \\
\text { Government }\end{array}$} & 4.286 & 0.828 & 0.737 & 0.291 & 0.198 & 0.183 & 0.036 & 0.163 & 0.110 \\
\hline & & & & [0.200;0.353] & {$[0.145 ; 0.320]$} & {$[0.069 ; 0.270]$} & {$[0.071 ; 0.137]$} & {$[0.068 ; 0.250]$} & [0.004;0.199] \\
\hline \multirow{2}{*}{$\begin{array}{l}\text { 2. Risk } \\
\text { Perception }\end{array}$} & 4.007 & 0.571 & 0.290 & 0.683 & 0.193 & 0.165 & 0.046 & 0.109 & 0.030 \\
\hline & & & & & {$[0.044 ; 0.312]$} & {$[0.263 ; 0.246]$} & {$[0.191 ; 0.124]$} & {$[0.289 ; 0.116]$} & [0.156;0.172] \\
\hline \multirow{2}{*}{$\begin{array}{l}3 . \\
\text { Satisfaction } \\
\text { with } \\
\text { Government } \\
\text { Measures }\end{array}$} & 5.815 & 0.951 & 0.302 & 0.278 & 0.523 & 0.373 & 0.054 & 0.061 & 0.128 \\
\hline & & & & & & {$[0.253 ; 0.449]$} & {$[0.051 ; 0.158]$} & {$[0.041 ; 0.156]$} & [0.009;0.234] \\
\hline \multirow{2}{*}{$\begin{array}{l}\text { 4. Self- } \\
\text { Efficacy }\end{array}$} & 4.771 & 0.954 & 0.181 & 0.347 & -0.057 & 0.572 & 0.145 & 0.090 & 0.037 \\
\hline & & & & & & & {$[0.048 ; 0.236]$} & {$[0.004 ; 0.196]$} & $\begin{array}{l}{[0.074 ;} \\
0.132]\end{array}$ \\
\hline \multirow[t]{2}{*}{ 5. Age } & 2.635 & 0.897 & 0.037 & 0.039 & 0.006 & 0.146 & N/A & 0.092 & 0.289 \\
\hline & & & & & & & & {$[0.027 ; 0.183]$} & {$[0.187 ; 0.358]$} \\
\hline \multirow[t]{2}{*}{ 6. Gender } & 1.665 & 0.473 & 0.163 & 0.091 & -0.005 & 0.092 & 0.092 & $\mathrm{~N} / \mathrm{A}$ & 0.289 \\
\hline & & & & & & & & & $\begin{array}{l}{[0.187 ;} \\
0.358]\end{array}$ \\
\hline $\begin{array}{l}7 . \\
\text { Education }\end{array}$ & 2.615 & 0.749 & 0.111 & 0.143 & -0.008 & 0.038 & 0.409 & 0.289 & N/A \\
\hline $\begin{array}{l}\text { Notes: Bold } \\
\text { respective me } \\
\text { are significan } \\
\text { diagonal are } \\
\text { level. }\end{array}$ & $\begin{array}{l}\text { ues on } \\
\text { sures. } 0 \\
\text { at } p<0 \text {. } \\
\text { e hetero }\end{array}$ & $\begin{array}{l}\text { e diago } \\
\text {-diagor } \\
\text { 5, and v } \\
\text { ait-mon }\end{array}$ & $\begin{array}{l}\text { al signi } \\
\text { eleme } \\
\text { ues hig } \\
\text { rait rat }\end{array}$ & $\begin{array}{l}\text { the square roc } \\
\text { s below the dia } \\
\text { ar than } 0.16 \text { ar } \\
\text { of the correla }\end{array}$ & $\begin{array}{l}\text { of the averag } \\
\text { onal are the cc } \\
\text { significant at } p \\
\text { ons (HTMT) ar }\end{array}$ & $\begin{array}{l}\text { variance extrac } \\
\text { elations amon } \\
0.01 \text { (two-taile } \\
\text { their respectiv }\end{array}$ & $\begin{array}{l}\text { d shared beth } \\
\text { the constructs } \\
\text { test). Off-diag } \\
\text { confidence int }\end{array}$ & $\begin{array}{l}\text { an the construc } \\
\text { alues between } \\
\text { al elements ab } \\
\text { rals at the } 95 \%\end{array}$ & $\begin{array}{l}\text { and their } \\
.12 \text { and } 0.15 \\
\text { ve the } \\
\text { onfidence }\end{array}$ \\
\hline
\end{tabular}

\section{Structural Model Assessment}

In explaining the dependent variable of this study (i.e., self-efficacy), among our demographic variables, only age showed a significant effect with self-efficacy, while the other variables (i.e., gender and education) displayed nonsignificant effects (see Table 4). Table 4 also presents the findings related to the hypotheses. In support of $\mathrm{H}_{1}$, the results illustrated that trust in the government significantly and positively influenced self-efficacy $(\beta=0.120, p<0.001)$. Additionally, the results revealed that as predicted in $\mathrm{H}_{2}$, risk perception positively shaped selfefficacy $(\beta=0.391, p<0.000)$. Thus, the findings revealed that both risk perception and trust in the government had a significant direct effect on individual self-efficacy, supporting $\mathrm{H}_{1}$ and $\mathrm{H}_{2}$.

Additionally, to test the interaction hypotheses $3 a$ and $3 b$, the standardized scores of the variables were used to minimize multicollinearity in the analysis (Low and Mohr 2001). Once the independent variables and moderator were introduced, their interactions with the moderator variable were included. As shown in Table 4, this process revealed a significant interaction effect between trust in the government and satisfaction with government measures on self-efficacy $(\beta=0.105, p<0.021)$ and between risk perception and satisfaction with government measures on self-efficacy $(\beta=0.204, p<0.018)$. Therefore, our proposed moderation was statistically significant. To help interpret these interaction effects, we followed previous recommendations by Dawson (2014) and plotted the high versus low satisfaction with government measures regression lines (+1 and -1 standard deviation from the mean) of each effect. The resulting graph of the first interaction effect shows that the positive relationship between trust in the government and self-efficacy is stronger (the slope is more pronounced) when individuals have a high level of satisfaction with government measures than when the level of satisfaction is low, supporting H3a (Figure 2). Regarding the second interaction effect, the graph reveals that the positive relationship between risk perception and self-efficacy is stronger 
(the slope is more pronounced) when individuals have a high level of satisfaction with government measures than when the level of satisfaction is low, supporting $\mathrm{H} 3 \mathrm{~b}$ (Figure 3).

\section{Table 4. Direct and Interaction Effects}

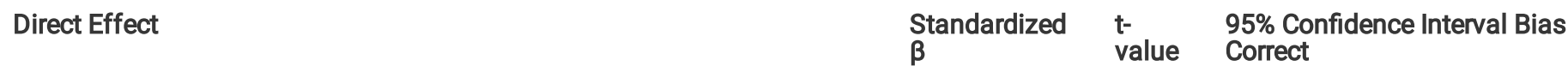

Self-Efficacy $\left(R^{2}=0.56\right)$

Trust in the Government

$0.120 * \star * \quad 2.064 \quad[0.039 ; 0.227] \mathrm{sig}$.

Risk Perception

$0.391^{\star \star \star} \quad 7.376 \quad[0.300 ; 0.475]$ sig.

\section{Interaction Effect}

Trust in the Government $x$ Satisfaction with the Government Measures Justice

Risk Perception x Satisfaction with Government Measures

$0.105^{\star *} \quad 2.045 \quad[0.015 ; 0.195] \mathrm{sig}$.

Control Variable

\begin{tabular}{llcc} 
Age & 0.154 & 3.091 & {$[0.114 ; 0.399] \mathrm{sig}$} \\
\hline Gender & -0.005 & 0.170 & {$[-0.004 ; 0.061] \mathrm{ns}$} \\
\hline Education & -0.006 & $0.616 \quad[-0.002 ; 0.071] \mathrm{ns}$
\end{tabular}

Notes: $* * * p<.001$ (one-tailed test): $\mathrm{t}_{(4,999)}=3.10, * \star \mathrm{p}<0.01$ (one-tailed test): $\mathrm{t}_{(4,999)}=2.33,{ }^{*} p<.05$ (one-tailed test): $\mathrm{t}_{(4,999)}=1.65 ;($ to test the effects of the control variables, a two-tailed test of a Student $t$ distribution was conducted instead). Bootstrapping based on $\mathrm{n}=$ 5,000 subsamples, where a bootstrap t-statistic with $n-1$ degrees of freedom was used ( $n$ is the number of subsamples); $n s=$ not significant, sig = significant.

Regarding the explanatory power of the suggested model, the model explains $0.56 \%$ of the total variance in self-efficacy (Table 4 ), which, according to Hair et al. (2017), implies a moderate to the large effect of this model on this variable. In addition, the Stone-Geisser blindfolding sample reuse technique revealed a Q-square value greater than 0; thus, the model effectively predicts self-efficacy (Q2 = 0.212 ) (Hair et al. 2017). Finally, we also checked the overall goodness-of-fit (GoF). The SRMR index (standardized root means square residual) had a value of 0.043 , which is far below the cutoff of 0.08 (Henseler 2017). Additionally, the SRMR's $95 \%$ bootstrap quantile is 0.051 and, thus, is higher than the SRMR value, indicating that the model has a good fit (Hair et al. 2017). The discrepancy indexes dULS (unweighted least squares discrepancy) and dG (geodesic discrepancy) are also under the bootstrap-based 95th percentile (dULS = $1.431<\mathrm{HI} 95$ of dULS = $2.512 ; \mathrm{dG}=$ $0.564<\mathrm{HI} 95$ of $\mathrm{dG}=0.989$ ) (Hair et al. 2017). Overall, the discrepancy between the empirical and model-implied correlation matrix is nonsignificant, suggesting that there is no reason to reject the model and that the tested model is likely valid (Henseler 2017).

\section{Discussion And Conclusion}

The main purpose of this enquiry was to explore the effect of government trust and perception of the risk during the COVID-19 pandemic on self-efficacy. In addition, this study aims to examine whether satisfaction with government measures improves the positive impact of government trust and perception of risk on self-efficacy. More specifically, we based our claim on the suggestion by Hussain (2020) that trust in a government's strategy and perception of risk is profoundly dependent on satisfaction with the government's measures to combat the spread of COVID-19. The results of this study thus enable us to draw meaningful results. First, government trust has been significantly related to self-efficacy, suggesting that individuals with high levels of government trust, particularly during the ongoing disease outbreak, have a high level of self-efficacy. Therefore, people who trust their government about a public health threat would probably have strong self-efficacy beliefs because trusting the government is a significant factor because it is difficult to manage the level of risk perceived by the public.

An important aspect of trust is the asymmetry principle. This approach refers to trust as a fragile construct as trust is fundamentally difficult to earn and can be easily destroyed (Slovic 1993). Also, the results reflect that overall, individuals trust their government and follow the government's strategies in managing a public health hazard. Hence, people perceive themselves to have strong personal control in the situation (Kasperson, Golding, and Tuler 1992; Vaughan and Tinker 2009). In contrast, individuals with a low level of trust exhibit a low level of self-efficacy, and such individuals are more worried, tense and anxious as they are unable to make the behavioral changes needed to protect themselves; however, individuals with a high level of trust in the government depend on their government for protection (Huurne, ter, 
and Gutteling 2009). Thus, according to the confidence model, when people trust their government, the public is encouraged to accept the government's decisions and adopt the recommended protective measures (Slovic 2000; Siegrist, Earle, and Gutscher 2003). Logically, trust in the government and self-efficacy are intertwined and are valid in this context (Griffin et al., 2008). Therefore, the current findings contribute to both knowledge and practice, especially regarding the importance of trust in the government during critical situations (e.g., the COVID-19 pandemic) (Paek, Hilyard, Freimuth, Barge, and Mindlin 2008).

Second, the relationship between risk perception and perceived self-efficacy during the current pandemic was found to be positively correlated. This relationship can be explained as people who perceive a high level of risk regarding COVID-19 are more likely to increase their individual self-efficacy beliefs. Thus, this finding is consistent with the theoretical proposition. In addition, individuals who perceive a high level of susceptibility and severity of COVID-19 are likely to adopt behavioral changes and implement protective measures (El-Toukhy 2015). Therefore, based on social motivation theory (SMT), people who perceive a high level of risk and have a high level of self-efficacy are viewed as responsive individuals who can adapt and implement protective health measures to ensure that they are protected and that their chances of becoming infected are low (Witte, 1992; Flora, Saphir, Schooler, and Rimal 1997). Therefore, risk perception is an influential factor in selfefficacy, particularly during the current pandemic.

When considering satisfaction with government measures, the study data reflect the following interesting phenomenon: the relationship between trust in the government and self-efficacy is stronger when people are highly satisfied with government measures. This finding can be explained by the fact that individuals trust their government to protect them during the current pandemic as this aspect enhances their belief in their ability to protect themselves from COVID-19, particularly when they are highly satisfied with the government measures implemented to combat the disease, and that during public health crises, people are more likely to comply with government measures (Bandura 1997; Siegrist et al. 2003). Similarly, as predicted, our results revealed that a relationship exists between risk perception of COVID-19 and self-efficacy. The analysis reveals the following exciting result: the relationship between risk perception and self-efficacy is stronger when people are highly satisfied with the government measures; furthermore, such individuals are aware of their susceptibility to and the severity of the virus and are motivated to implement precautionary actions (self-efficacy) (Flora et al. 1997; Slovic 2000). Specifically, the relationship is stronger when the levels of satisfaction with the government measures implemented to combat COVID-19 are higher. Hence, this study sheds light on the importance of satisfaction with government measures during a pandemic, the critical role of satisfaction in shaping risk perception regarding COVID-19 and individuals' ability to adapt personal preventive measures (Rimal and Real 2003; van der Weerd, Timmermans, Beaujean, Oudhoff, and van Steenbergen, 2011).

\section{Limitations and Future Research}

The first limitation of this research is that sampling for the analysis was performed through the researchers' networks through a convenience survey and distributed through various social media platforms (WhatsApp, Facebook, Twitter, etc). Consequently, bias is likely as disadvantaged populations may not have been able to participate in the sample. Therefore, the generalizability of the results often has limitations. To boost the representativeness and generalizability of the results, a more systematic, comprehensive sampling approach is needed. Another drawback to this analysis is the likelihood that socially acceptable responses were provided by the participants. Because this research utilized self-reported data, the respondents could have responded to questions about the behavior and behaviors differently depending on what they felt was expected of them (Van de Mortel 2008). Therefore, we urge academic scholars to perform more work using more longitudinal or experiential studies to examine the relationship between these variables to clearly observe the dynamic shifts in trust, risk, and self-efficacy. Finally, earlier research indicates that the sources people use to obtain information regarding the pandemic, such as social media or official news outlets, considerably impact the cognitive issues of both individuals and groups (Tsui, Rao, Carey, Feng, and Provencher 2020; Wiederhold 2020). Thus, the structures examined here may be influenced by other factors or variables missing from this study, such as social media usage or social media exposure. Hence, the use and impact of social media during the COVID-19 crisis need further investigation.

\section{Conclusion}

In this study, we highlight the degree of trust Swedish citizens have in their government and their self-awareness of the risk of COVID-19. As indicated by the findings, Swedish citizens have a high level of trust in their government to protect them during the pandemic and a high level of perceived risk from the current pandemic, both of which enhance individuals' awareness of the risk posed by COVID-19. Therefore, these factors enhance their belief in their ability to adopt the recommended preventive measures and undergo behavioral changes to combat the spread of COVID-19 in Sweden. Importantly, as revealed in this study, Swedish people are likely satisfied with the government measures implemented to combat the virus, and, in turn, their satisfaction with the government measures augments the positive effect of trust in the government and risk perception on self-efficacy. Therefore, the findings of this study are significant as they highlight that during the pandemic, while governments worldwide are implementing measures, such as social distancing, nationwide lockdowns and stay-at-home 
orders (Hussain 2020), peoples' satisfaction with these government measures plays a critical role in the ability of the public to protect themselves and in shaping their trust in the government and how to perceive the risk of thread.

\section{Declarations}

\section{Ethics declarations}

Conflict of Interest: The authors declare that they have no conflict of interest

Ethical Approval: This study was approved by the University of Malaya Research Ethics Committee (Approval No UM. TNC2/UMREC - 967).

Informed Consent: Informed consent was obtained from all individual participants included in the study

Funding: The author(s) received no specific funding for this work.

\section{References}

1. Anderson, J. (2020). Sweden's very different approach to Covid-19. Retrieved from https://qz.com/1842183/sweden-is-taking-a-verydifferent-approach-to-covid-19/

2. Anderson, R. M., \& May, R. M. (1985). Vaccination and herd immunity to infectious diseases. Nature, 318(6044), 323-329. DOI: $10.1038 / 318323 a 0$

3. Bandura, A. (1990). Perceived self-efficacy in the exercise of control over AIDS infection. Evaluation and program planning, 13(1), 9-17. doi: org/10.1016/0149-7189(90)90004-G

4. Bandura, A. (1997). Self-efficacy: The exercise of control. H. FreemanNew York, NY.

5. Bandura, A., \& Watts, R. E. (1996). Self-efficacy in changing societies. In: Springer.

6. Becker, T. E. (2005). Potential problems in the statistical control of variables in organizational research: A qualitative analysis with recommendations. Organizational research methods, 8(3), 274-289. DOI. org/10.1177/1094428105278021

7. Blair, R. A., Morse, B. S., \& Tsai, L. L. (2017). Public health and public trust: Survey evidence from the Ebola Virus Disease epidemic in Liberia. Social science \& medicine, 172, 89-97. doi: 10.1016/j.socscimed.2016.11.016

8. Boda, Z., \& Medve-Balint, G. (2014). Does Institutional Trust in East Central Europe Differ from Western Europe? European Quarterly of Political Attitudes and Mentalities, 3(2), 1.

9. Brueck, H. (2020). Sweden's gamble on coronavirus herd immunity couldn't work in the US - and it may not work in Sweden. Retrieved from https://www.businessinsider.my/sweden-coronavirus-strategy-explained-culture-of-trust-and-obedience-2020

10. Choi, D.-H., Yoo, W., Noh, G.-Y., \& Park, K. (2017). The impact of social media on risk perceptions during the MERS outbreak in South Korea. Computers in Human Behavior, 72, 422-431. DOI: 10.1016/j.chb.2017.03.004

11. Cohen, J. (1992). A power primer. Psychological bulletin, 112(1), 155. doi: org/10.1037/0033-2909.112.1.155

12. Cole, L. M., \& Cohn, E. S. (2016). Institutional trust across cultures: Its definitions, conceptualizations, and antecedents across Eastern and Western European Nations. In Interdisciplinary Perspectives on Trust (pp. 157-176): Springer. doi.org/10.1007/978-3-319-22261-5_9

13. Coleman, D., \& Iso-Ahola, S. E. (1993). Leisure and health: The role of social support and self-determination. Journal of leisure research, 25(2), 111-128.doi: org/10.1080/00222216.1993.11969913

14. d'souza, G., \& dowdy, D. (2020). What is Herd Immunity and How Can We Achieve It With COVID-19? Retrieved from https://www.jhsph.edu/covid-19/articles/achieving-herd-immunity-with-covid19.html

15. Dawson, J. F. (2014). Moderation in Management Research: What, Why, When, and How. Journal of Business and Psychology, 29(1), 119. DOI:10.1007/s10869-013-9308-7. doi: 10.1007/s10869-013-9308-7

16. Dinesen, P. T., \& Jæger, M. M. (2013). The Effect of Terror on Institutional Trust: New Evidence from the 3/11 Madrid Terrorist Attack. Political Psychology, 34(6), 917-926. DOI: org/10.1111/pops.12025

17. Dorsey, A. M., Miller, K. I., \& Scherer, C. W. (1999). Communication, risk behavior, and perceptions of threat and efficacy: A test of a reciprocal model.

18. El-Toukhy, S. (2015). Parsing susceptibility and severity dimensions of health risk perceptions. Journal of health communication, 20(5), 499-511. Retrieved from https://www.tandfonline.com/doi/full/10.1080/10810730.2014.989342

19. Feldman, K. (2020). Sweden claims coronavirus success after keeping country open, says herd immunity imminent. Retrieved from https://www.msn.com/en-us/news/world/sweden-claims-coronavirus-success-after-keeping-country-open-says-herd-immunity-imminent 
20. Fenner, F., Henderson, D. A., Arita, I., Jezek, Z., \& Ladnyi, I. D. (1988). Smallpox and its eradication (Vol. 6): World Health Organization Geneva.

21. Fine, P. E. (1993). Herd immunity: history, theory, practice. Epidemiologic reviews, 15(2), 265-302. doi: 10.1093/oxfordjournals.epirev.a036121

22. Flora, J. A., Saphir, M. N., Schooler, C., \& Rimal, R. N. (1997). Toward a framework for intervention channels: Reach, involvement, and impact. Annals of epidemiology, 7(7), S104-S112.

23. Fox, J. P. (1983). Herd Immunity and Measles. Reviews of Infectious Diseases, 5(3), 463-466. Retrieved from www.jstor.org/stable/4453057. doi: org/10.1093/clinids/5.3.463

24. Griffin, R. J., Yang, Z., Ter Huurne, E., Boerner, F., Ortiz, S., \& Dunwoody, S. (2008). After the flood: Anger, attribution, and the seeking of information. Science communication, 29(3), 285-315. doi: org/10.1177/1075547007312309

25. Grimmelikhuijsen, S. (2012). Linking Transparency, Knowledge and Citizen Trust in Government: An Experiment. International Review of Administrative Sciences - INT REV ADM SCI, 78, 50-73. doi:10.1177/0020852311429667

26. Hair, J. F., Hult, G. T. M., Ringle, C., \& Sarstedt, M. (2017). A primer on partial least squares structural equation modeling (PLS-SEM) (2st ed.): Sage Publications.

27. Hair, J. F., Risher, J. J., Sarstedt, M., \& Ringle, C. M. (2019). When to use and how to report the results of PLS-SEM. European business review.

28. Han, G., Zhang, J., Chu, K., \& Shen, G. (2014). Self-other differences in H1N1 flu risk perception in a global context: a comparative study between the United States and China. Health communication, 29(2), 109-123. doi: 10.1080/10410236.2012.723267

29. Harman, H. H. (1976). Modern factor analysis: University of Chicago press.

30. Henseler, J. (2017). Bridging design and behavioral research with variance-based structural equation modeling. Journal of advertising, 46(1), 178-192. doi: org/10.1080/00913367.2017.1281780

31. Henseler, J., Ringle, C. M., \& Sarstedt, M. (2015). A new criterion for assessing discriminant validity in variance-based structural equation modeling. Journal of the Academy of Marketing Science, 43(1), 115-135. doi: 10.1007/s11747-014-0403-8

32. Henseler, J., Ringle, C. M., \& Sinkovics, R. R. (2009). The use of partial least squares path modeling in international marketing. In New challenges to international marketing: Emerald Group Publishing Limited. doi: 10.1108/S1474-7979(2009)0000020014

33. Hudson, J. (2006). Institutional trust and subjective well-being across the EU. Kyklos, 59(1), 43-62. doi: org/10.1111/j.14676435.2006.00319.x

34. Hussain, A. H. M. B. (2020). Do governments' decisions on social distancing flatten out people's mobility during COVID-19 pandemic? SSRN Electronic Journal. doi:10.2139/ssrn.3574979

35. Huurne, ter, E. F. J., \& Gutteling, J. (2009). How to Trust? The Importance of Self-Efficacy and Social Trust in Public Responses to Industrial Risks. Journal of Risk Research, 12, 809 - 824. doi:10.1080/13669870902726091

36. John, T. J., \& Samuel, R. (2000). Herd immunity and herd effect: new insights and definitions. Eur J Epidemiol, 16(7), 601-606. doi:10.1023/a:1007626510002

37. Kasperson, R. E., Golding, D., \& Tuler, S. (1992). Social distrust as a factor in siting hazardous facilities and communicating risks. Journal of social issues, 48(4), 161-187. doi: org/10.1111/j.1540-4560.1992.tb01950.x

38. Kock, N. (2015). Common method bias in PLS-SEM: A full collinearity assessment approach. International Journal of e-Collaboration (ijec), 11(4), 1-10. doi: 10.4018/ijec.2015100101

39. Kock, N., \& Lynn, G. (2012). Lateral collinearity and misleading results in variance-based SEM: An illustration and recommendations. Journal of the Association for Information Systems, 13(7). doi: 10.17705/1jais.00302

40. Kwok, K. O., Lai, F., Wei, W. I., Wong, S. Y. S., \& Tang, J. W. (2020). Herd immunity-estimating the level required to halt the COVID-19 epidemics in affected countries. Journal of Infection. doi:10.1016/j.jinf.2020.03.027

41. Latané, B., Liu, J. H., Nowak, A., Bonevento, M., \& Zheng, L. (1995). Distance matters: Physical space and social impact. Personality and Social Psychology Bulletin, 21(8), 795-805. doi.org/10.1177/0146167295218002

42. Locke, E. A., \& Latham, G. P. (1990). A theory of goal setting \& task performance: Prentice-Hall, Inc.

43. Low, G. S., \& Mohr, J. J. (2001). Factors affecting the use of information in the evaluation of marketing communications productivity. Journal of the Academy of Marketing Science, 29(1), 70-88. doi: org/10.1177/0092070301291005

44. MacKenzie, S. B., \& Podsakoff, P. M. (2012). Common method bias in marketing: causes, mechanisms, and procedural remedies. Journal of retailing, 88(4), 542-555. doi: 10.1016/j.jretai.2012.08.001 
45. Mai, H. J. (2020). Swedish Ambassador Says Stockholm Expected To Reach 'Herd Immunity' In May. Retrieved from https://www.npr.org/2020/04/26/845211085

46. Marien, S., \& Werner, H. (2019). Fair treatment, fair play? The relationship between fair treatment perceptions, political trust and compliant and cooperative attitudes cross-nationally. European Journal of Political Research, 58(1), 72-95. doi: org/10.1111/14756765.12271

47. Marozzi, M. (2015). Measuring trust in European public institutions. Social Indicators Research, 123(3), 879-895. DOI: 10.1007/s11205014-0765-9

48. Metcalf, C. J. E., Ferrari, M., Graham, A. L., \& Grenfell, B. T. (2015). Understanding herd immunity. Trends in immunology, 36(12), 753-755. doi: 10.1016/j.it.2015.10.004

49. Meunier, T. A. (2020). Full lockdown policies in Western Europe countries have no evident impacts on the COVID-19 epidemic. medRxiv.

50. Morse, S. S. (1996). Emerging viruses: Oxford University Press on Demand.

51. Newton, K. (2001). Trust, social capital, civil society, and democracy. International political science review, 22(2), 201-214. doi: org/10.1177/0192512101222004

52. Nikel, D. (2020). Sweden: 22 Scientists Say Coronavirus Strategy Has Failed As Deaths Top 1,000. Retrieved from https://www.forbes.com/sites/davidnikel/2020/04/14/sweden-22-scientists-say-coronavirus-strategy-has-failed-as-deaths-top-1000

53. Norris, F. H., Stevens, S. P., Pfefferbaum, B., Wyche, K. F., \& Pfefferbaum, R. L. (2008). Community resilience as a metaphor, theory, set of capacities, and strategy for disaster readiness. American journal of community psychology, 41(1-2), 127-150. doi: 10.1007/s10464-0079156-6

54. Nyheter, D. (2020). Folkhälsomyndigheten har misslyckats - nu måste politikerna gripa in”. Retrieved from https://www.dn.se/debatt/folkhalsomyndigheten-har-misslyckats-nu-maste-politikerna-gripa-in/

55. Oh, O., Eom, C., \& Rao, H. R. (2015). Research note-Role of social media in social change: An analysis of collective sense making during the 2011 Egypt revolution. Information Systems Research, 26(1), 210-223. doi: 10.1287/isre.2015.0565

56. Paek, H.-J., Hilyard, K., Freimuth, V. S., Barge, J. K., \& Mindlin, M. (2008). Public support for government actions during a flu pandemic: lessons learned from a statewide survey. Health promotion practice, 9(4_suppl), 60S-72S. doi: 10.1177/1524839908322114

57. Pask, E. B., \& Rawlins, S. T. (2016). Men's intentions to engage in behaviors to protect against human papillomavirus (HPV): Testing the risk perception attitude framework. Health communication, 31(2), 139-149. doi: 10.1080/10410236.2014.940670

58. Podsakoff, P. M., MacKenzie, S. B., Lee, J.-Y., \& Podsakoff, N. P. (2003). Common method biases in behavioral research: A critical review of the literature and recommended remedies. Journal of applied psychology, 88(5), 879. doi: 10.1037/0021-9101.88.5.879

59. Remland, M. S., Jones, T. S., \& Brinkman, H. (1995). Interpersonal distance, body orientation, and touch: Effects of culture, gender, and age. The Journal of social psychology, 135(3), 281-297. doi: 10.1080/00224545.1995.9713958

60. Reynolds, B., \& Seeger, m. (2005). Crisis and emergency risk communication as an integrative model. Journal of health communication, 10(1), 43-55. doi: org/10.1080/10810730590904571

61. Reynolds, E. (2020). Sweden's death rate rises amid herd immunity strategy. Retrieved from https://www.newstalkzb.co.nz/news/world/swedens-death-rate-rises-amid-herd-immunity-strategy/

62. Rimal, R. N., \& Real, K. (2003). Perceived risk and efficacy beliefs as motivators of change: Use of the risk perception attitude (RPA) framework to understand health behaviors. Human communication research, 29(3), 370-399. doi: org/10.1111/j.14682958.2003.tb00844.x

63. Rogers, R. W. (1983). Cognitive and psychological processes in fear appeals and attitude change: A revised theory of protection motivation. Social psychophysiology: A sourcebook, 153-176.

64. Rolander, N. (2020). Sweden Says Controversial Virus Strategy Proving Effective. Retrieved from https://www.bloomberg.com/news/articles/2020-04-19/sweden-says-controversial-covid-19-strategy-is-proving-effective

65. Rowe, R., \& Calnan, M. (2006). Trust relations in health care-the new agenda. The European Journal of Public Health, 16(1), 4-6. doi:10.1093/eurpub/ckl004

66. Rubin, G. J., Amlôt, R., Page, L., \& Wessely, S. (2009). Public perceptions, anxiety, and behaviour change in relation to the swine flu outbreak: cross sectional telephone survey. Bmj, 339, b2651. doi: https://doi.org/10.1136/bmj.b2651

67. Rubin, G. J., Bakhshi, S., Amlôt, R., Fear, N., Potts, H. W. W., \& Michie, S. (2014). Health Services and Delivery Research. In The design of a survey questionnaire to measure perceptions and behaviour during an influenza pandemic: the Flu TElephone Survey Template (FluTEST). Southampton (UK): NIHR Journals Library. doi:10.3310/hsdr02410

68. Schwarzer, R., \& Fuchs, R. (1996). Self-efficacy and health behaviours. Predicting health behavior: Research and practice with social cognition models, 163, 196. 
69. Siegrist, M., Earle, T. C., \& Gutscher, H. (2003). Test of a trust and confidence model in the applied context of electromagnetic field (EMF) risks. Risk Analysis: An International Journal, 23(4), 705-716. doi:10.1111/1539-6924.00349

70. Slovic, P. (1993). Perceived risk, trust, and democracy. Risk analysis, 13(6), 675-682. doi: org/10.1111/j.1539-6924.1993.tb01329.x.

71. Slovic, P. E. (2000). The perception of risk. Earthscan publications.

72. Sønderskov, K. M., \& Dinesen, P. T. (2016). Trusting the state, trusting each other? The effect of institutional trust on social trust. Political Behavior, 38(1), 179-202. doi:10.1007/s11109-015-9322-8.

73. Sorokowska, A., Sorokowski, P., Hilpert, P., Cantarero, K., Frackowiak, T., Ahmadi, K., . . Bettache, K. (2017). Preferred interpersonal distances: a global comparison. Journal of Cross-Cultural Psychology, 48(4), 577-592. doi: org/10.1177/0022022117698039

74. Strategy in response to the COVID-19 pandemic. (2020). Government offices of Sweden Retrieved from https://www.government.se/articles/2020/04/strategy-in-response-to-the-covid-19-pandemic.

75. Tang, C. S.-K., \& Wong, C.-Y. (2005). Psychosocial factors influencing the practice of preventive behaviors against the severe acute respiratory syndrome among older Chinese in Hong Kong. Journal of aging and health, 17(4), 490-506.doi: 10.1177/0898264305277966

76. Ter Huurne, E. F., \& Gutteling, J. M. (2009). How to trust? The importance of self-efficacy and social trust in public responses to industrial risks. Journal of Risk Research, 12(6), 809-824. doi: org/10.1080/13669870902726091.

77. Thaker, J., Howe, P., Leiserowitz, A., \& Maibach, E. (2019). Perceived Collective Efficacy and Trust in Government Influence Public Engagement with Climate Change-Related Water Conservation Policies. Environmental Communication, 13(5), 681-699. doi: org/10.1080/17524032.2018.1438302.

78. Tsui, E., Rao, R. C., Carey, A. R., Feng, M. T., \& Provencher, L. M. (2020). Using Social Media to Disseminate Ophthalmic Information During the COVID19 Pandemic. Ophthalmology. doi:10.1016/j.ophtha.2020.05.048

79. Uslaner, E. M. (2002). The moral foundations of trust. Cambridge University Press.

80. van der Weerd, W., Timmermans, D. R., Beaujean, D. J., Oudhoff, J., \& van Steenbergen, J. E. (2011). Monitoring the level of government trust, risk perception and intention of the general public to adopt protective measures during the influenza A ( $\mathrm{H} 1 \mathrm{~N} 1)$ pandemic in The Netherlands. BMC public health, 11, 575-575. doi:10.1186/1471-2458-11-575.

81. Van de Mortel, T. F. (2008). Faking it: social desirability response bias in self-report research. Australian Journal of Advanced Nursing, The, 25(4), 40.

82. Vaughan, E., \& Tinker, T. (2009). Effective health risk communication about pandemic influenza for vulnerable populations. American Journal of Public Health, 99(S2), S324-S332. doi: 10.2105/AJPH.2009.162537

83. Vinck, P., Pham, P. N., Bindu, K. K., Bedford, J., \& Nilles, E. J. (2019). Institutional trust and misinformation in the response to the 2018-19 Ebola outbreak in North Kivu, DR Congo: a population-based survey. The Lancet Infectious Diseases, 19(5), 529-536. doi:10.1016/S14733099(19)30063-5.

84. Wiederhold, B. K. (2020). Using social media to our advantage: Alleviating anxiety during a pandemic. Cyberpsychology, Behavior, and Social Networking, 23(4), 197-198. doi: org/10.1089/cyber.2020.29180.bkw

85. Willems, J., Knassmüller, M., Ebinger, F., Dinhof, K., \& Schmid, M. (2020). Austria in the COVID-19 Pandemic-Citizens' Satisfaction with Crisis Measures and Communication.

86. Williams, J. R. (2006). 15 - Models for the Study of Infection in Populations. In P. M. Conn (Ed.), Handbook of Models for Human Aging (pp. 165-182). Burlington: Academic Press.

87. Witte, K. (1992). Putting the fear back into fear appeals: The extended parallel process model. Communications Monographs, 59(4), 329349. doi: org/10.1080/03637759209376276

88. Wltz. (2020). Sweden Confirms First Coronavirus Case. Retrieved from https://www.wltz.com/2020/02/03/sweden-confirms-firstcoronavirus-case/

89. World Health Organization, W. (2020). Coronavirus disease 2019 (COVID-19): situation report, 141.

90. Zhu, N., Zhang, D., Wang, W., Li, X., Yang, B., Song, J., . . Tan, W. (2020). A Novel Coronavirus from Patients with Pneumonia in China, 2019. New England Journal of Medicine, 382(8), 727-733. doi:10.1056/NEJMoa2001017.

\section{Figures}




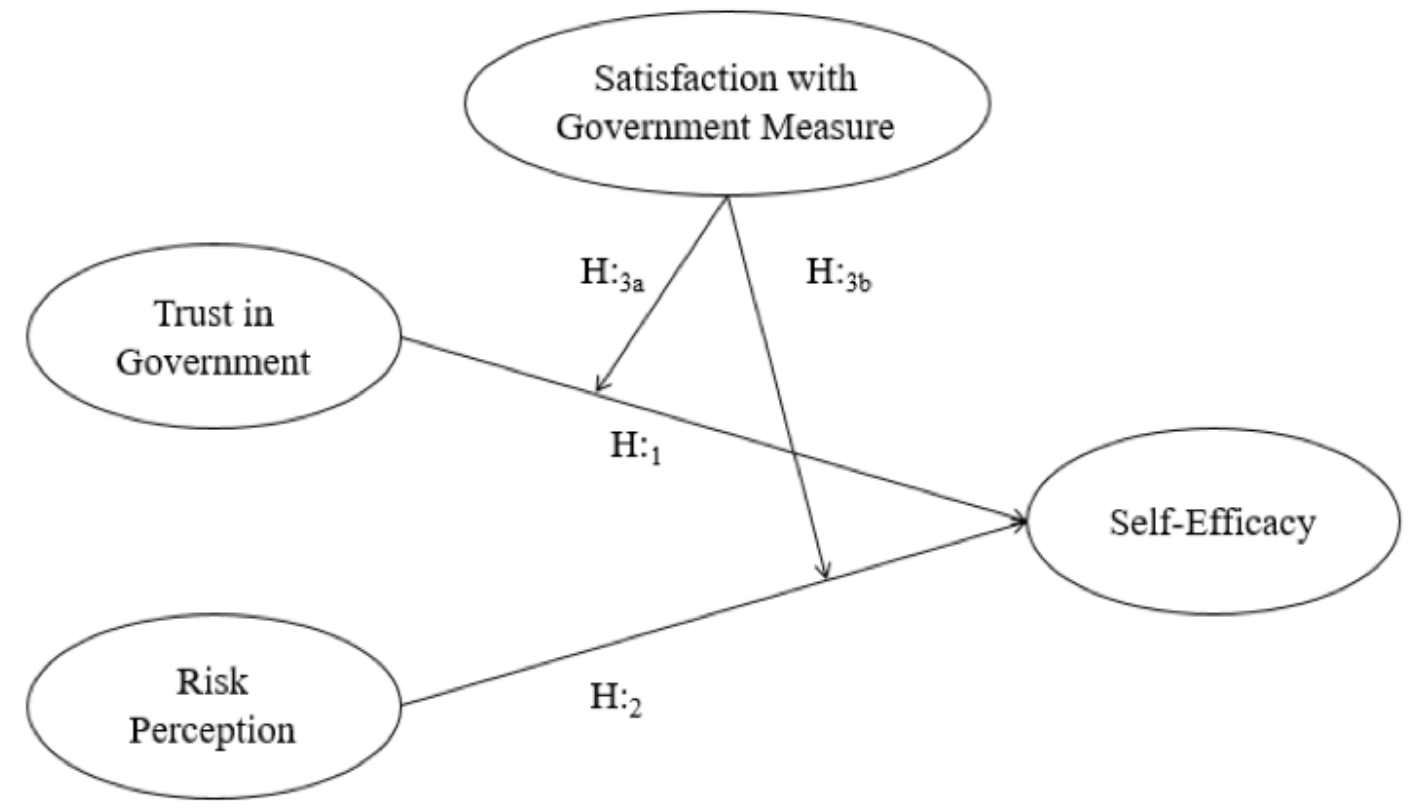

Figure 1

Research Model

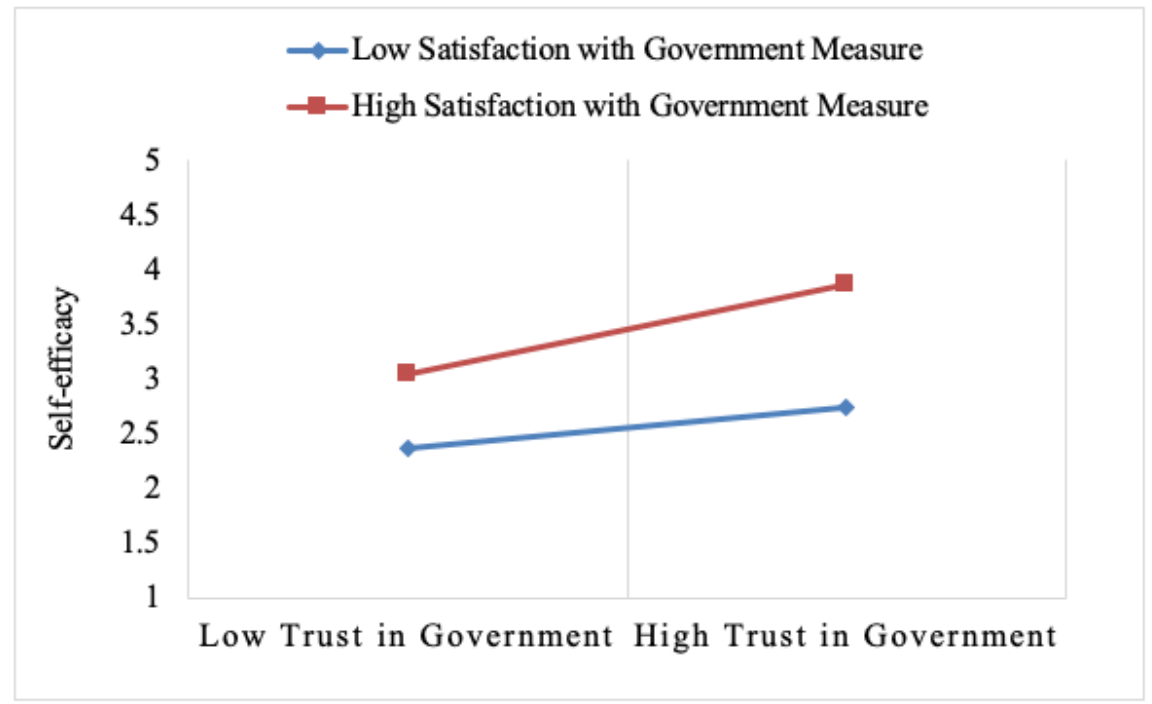

Figure 2

Interaction effects between trust in the government and satisfaction with government measures on self-efficacy 


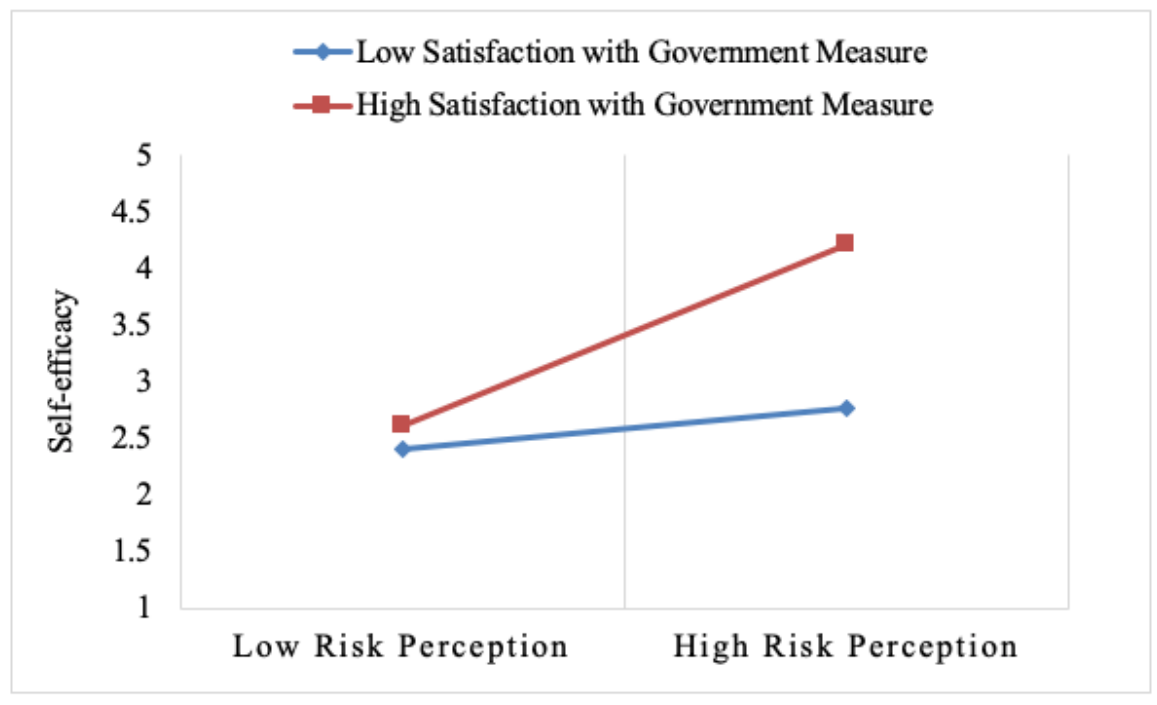

Figure 3

Interacting effects between risk perception and satisfaction with government measures on self-efficacy 